\title{
DAYA HAMBAT NaCI TERHADAP PERTUMBUHAN Staphylococcus aureus
}

\author{
Amalia, Ratih Dewi Dwiyanti, Haitami \\ Jurusan Analis Kesehatan Poltekkes Kemenkes Banjarmasin \\ JI Mistar Cokrokusumo 4a Banjarbaru \\ e-mail: haitami4@yahoo.co.id
}

\begin{abstract}
Staphylococcus aureus is a pathogenic bacterial that causes infectious disease and human poisoning through enterotoxin produced by the bacteria. Salt or sodium chloride is used by human for food preservation process because it can inhibit the growth of bacteria, especially Staphylococcus aureus. The purposes of the study were to determine the effect of $\mathrm{NaCl}$ in media on the growth of Staphylococcus aureus and determine the effective concentration of $\mathrm{NaCl}$. The type of research used in this study was true experiment posttest only control group design. Samples were prepared in $5 \mathrm{NaCl}$ concentrations, they were 10\%, 15\%, 20\%, 25\% dan $30 \%$. The study conclusion was there were effects of $\mathrm{NaCl}$ addition to the media on the growth of Staphylococcus aureus with a significance value of $0.000(<0.05)$. The effective $\mathrm{NaCl}$ concentration that inhibited the growth of Staphylococcus aureus is $15 \%$. The advice for next study is to conduct similar studies with $\mathrm{NaCl}$ concentration of $10 \%-15 \%$.
\end{abstract}

Keywords: Staphylococcus aureus; Sodium Chloride

Abstrak: Staphylococcus aureus merupakan bakteri patogen yang menyebabkan penyakit infeksi dan keracunan pada manusia melalui enterotoksin yang dihasilkan oleh bakteri tersebut. Garam dapur atau natrium klorida dimanfaatkan oleh manusia untuk proses pengawetan makanan karena dapat menghambat pertumbuhan bakteri khususnya Staphylococcus aureus. Tujuan penelitian adalah untuk mengetahui pengaruh penambahan $\mathrm{NaCl}$ pada media terhadap pertumbuhan Staphylococcus aureus dan menentukan konsentrasi efektif dari $\mathrm{NaCl}$. Jenis penelitian yang digunakan dalam penelitian adalah true experiment dengan rancangan posttest only control group design. Sampel penelitian adalah $\mathrm{NaCl}$ yang dibuat dalam 5 konsentrasi, yaitu $10 \%, 15 \%, 20 \%, 25 \%$ dan $30 \%$. Penelitian dilakukan dengan teknik cawan sebar pada media nutrien agar. Hasil penelitian menunjukkan bahwa tidak terdapat koloni Staphylococcus aureus pada media dengan penambahan $\mathrm{NaCl}$ konsentrasi $15 \%$ sampai konsentrasi $30 \%$. Kesimpulan penelitian terdapat pengaruh penambahan $\mathrm{NaCl}$ pada media terhadap pertumbuhan Staphylococcus aureus dengan nilai signifikasi 0,000 $(<0,05)$. Konsentrasi $\mathrm{NaCl}$ yang efektif menghambat pertumbuhan Staphylococcus aureus adalah 15\%. Saran untuk melakukan penelitian yang serupa dengan konsentrasi $\mathrm{NaCl} 10 \%-15 \%$.

Kata kunci: Staphylococcus aureus; natrium clorida 


\section{PENDAHULUAN}

Natrium klorida atau yang biasa disebut garam dapur adalah senyawa dengan rumus $\mathrm{NaCl}$. Dalam suatu proses fermentasi bahan pangan, natrium klorida bermanfaat untuk membatasi pertumbuhan organisme pembusuk dan mencegah pertumbuhan sebagian organisme. Namun, bakteri tertentu masih dapat tumbuh dalam larutan berkadar garam tinggi (Desrosier, 2008).

Garam merupakan salah satu bahan pembantu yang sangat penting bagi manusia salah satunya garam digunakan untuk proses pengawetan ikan. Selain itu garam juga mempunyai peran dalam menghambat pertumbuhan bakteri khususnya Staphylococcus aureus (Indarti, 2009).

Garam dapat memperpanjang umur simpan produk, karena garam mempunyai sifat bakteriosid (daya membunuh) dan bakteriostatik (daya menghambat). Aksi osmotik larutan garam terhadap bahan pangan disebabkan karena bahan pangan bertindak sebagai membran semipermiabel menurunkan kadar air sehingga garam berperan untuk menghambat kegiatan bakteriologis dan enzimatis (Ilyas dan Arifudin dalam Helmiyati, 2010).

Staphylococcus aureus adalah bakteri berbentuk bulat, bersifat gram positif, biasanya tersusun dalam rangkaian tidak beraturan seperti buah anggur. Beberapa diantaranya tergolong flora normal pada kulit dan selaput mukosa manusia, menyebabkan abses, berbagai infeksi piogen dan bahkan septikemia yang fatal. Staphylococcus aureus mengandung polisakarida dan protein yang berfungsi sebagai antigen dan merupakan substansi penting didalam struktur dinding sel, tidak membentuk spora, dan tidak membentuk flagel (Jawetz et al., 2008).

Staphylococcus aureus merupakan flora normal kulit dan saluran nafas atas pada individu yang carrier (Honeyman, 2001). Staphylococcus aureus memproduksi Staphylococcal enterotoxins (SE) yaitu bersifat patogen yang dapat menyebabkan keracunan pangan. Gejala umum keracunan SE ditandai dengan mual, muntah, kram perut dan diare yang terjadi selama 24 - 48 jam, masa penyembuhan biasanya terjadi antara 1-3 hari (Balaban\& Rasooly, 2000).

Laporan tahunan BPOM tahun 2009 menunjukkan bahwa pada tahun 2009 di Indonesia telah terjadi 115 kejadian luar biasa (KLB) karena keracunan pangan. Berdasarkan data BPOM kemungkinan Staphylococcus aureus adalah salah satu penyebab kera- cunan di Indonesia karena Staphylococcus aureus merupakan flora normal yang secara alami terdapat pada tubuh manusia dan dapat mengkontaminasi makanan yang diolah dengan kondisi sanitasi kurang baik. Di Kalimantan Selatan terjadi keracunan massal sebanyak 72 pasien 1 diantaranya meninggal dunia. Rata-rata pasien mengeluh sakit diare, muntah-muntah dan sakit perut. Berdasarkan hasil penelitian dari laboratorium Balai Besar Tekhnologi Kesehatan Lingkungan dan Pencegahan Penyakit (BBTKLPP) Banjarbaru, makanan yang terkontaminasi adalah kare ayam positif mengandung bakteri Staphylococcus aureus (Jaya, 2013)

Staphylococcus aureus merupakan bakteri tahan garam dan tumbuh baik pada media yang mengandung $7,5 \% \mathrm{NaCl}$, seperti halnya pada media manithol salt agar (MSA) (Srikandi, 1993).

Hasil penelitian Dini Ruliani (2010) pengaruh larutan garam dapur terhadap pertumbuhan Staphylococcus aureus pada media nutrient agar menunjukkan terdapat pengaruh larutan garam dapur $(\mathrm{NaCl})$ pada konsentrasi $18 \%$. Dalam penelitian Indra Aristyan et al., (2014) pada proses pembuatan terasi dengan perbedaan penambahan garam (2\%, 8,5\% dan 15\%) mempengaruhi kualitas organoleptik dan mikrobiologis terasi rebon. Semakin tinggi kadar garam semakin rendah pertumbuhan bakteri Staphylococcus aureus dan bakteri halofilik. Tujuan penelitian ini adalah untuk mengetahui pengaruh penambahan $\mathrm{NaCl}$ dalam media terhadap pertumbuhan Staphylococcus aureus dan menentukan konsentrasi efektif dari $\mathrm{NaCl}$.

\section{BAHAN DAN METODE}

Jenis penelitian yang digunakan dalam penelitian ini adalah true experiment. Rancangan penelitian yang digunakan adalah posttest dengan kelompok kontrol (posttest only control group design). Sampel penelitian ini adalah $\mathrm{NaCl}$ yang akan dibuat dalam 5 konsentrasi, yaitu $10 \%, 15 \%, 20 \%, 25 \%$ dan $30 \%$. Variabel bebas dari penelitian ini adalah $\mathrm{NaCl}$ dengan konsentrasi 10\%, 15\%, 20\%, $25 \%$ dan $30 \%$. Variabel terikat dalam penelitian ini adalah jumlah koloni Staphylococcus aureus pada media Nutrient Agar (NA) merck dengan konsentrasi $\mathrm{NaCl} 10 \%, 15 \%$, $20 \%, 25 \%$ dan 30\%. Penelitian ini dilakukan dengan cara koloni kuman Staphylococcus aureus pada media Manit Salt Agar (MSA) merck dihomogenkan ke dalam tabung reaksi yang berisi $10 \mathrm{ml}$ larutan $\mathrm{NaCl} \mathrm{0,9 \%}$ steril. 
Kekeruhan suspensi kuman pada larutan $\mathrm{NaCl}$ 0,9\% disamakan dengan standar Mc Farland 0,5 yang setara dengan $150 \mathrm{juta} / \mathrm{ml}$. Ambil $10 \mu$ l suspensi Staphylococcus aureus yang telah disamakan kekeruhannya dengan Mc Farland 0,5 dimasukkan dalam media Nutrient Agar (NA) yang telah ditambah $\mathrm{NaCl}$ dengan konsentrasi 10\%, 15\%, 20\%, 25\% dan 30\% kemudian disebarkan dengan menggunakan segitiga bengkok dan inkubasi pada suhu $37^{\circ} \mathrm{C}$ selama 24 jam. Ambil $10 \mu \mathrm{l}$ suspensi Staphylococcus aureus yang telah disamakan kekeruhannya dengan Mc Farland 0,5 dimasukkan dalam media Nutrient Agar (NA) tanpa penambahan $\mathrm{NaCl}$ sebagai kontrol, inkubasi pada suhu $37^{\circ} \mathrm{C}$ selama 24 jam. Amati dan hitung jumlah koloni yang tumbuh pada media yang ditambah $\mathrm{NaCl}$ pada konsentrasi yang berbeda, serta pada media Nutrien Agar (NA) tanpa penambahan $\mathrm{NaCl}$ atau kontrol.

\section{HASIL DAN PEMBAHASAN}

Hasil pengujian pertumbuhan koloni Staphylococcus aureus pada konsentrasi $\mathrm{NaCl}$ yang berbeda disajikan pada tabel 1 .

Tabel 1. Pertumbuhan koloni Staphylococcus aureus

\begin{tabular}{ccccccc}
\hline Variasi & \multicolumn{6}{c}{ Jumlah Koloni Staphylococcus aureus } \\
\cline { 2 - 6 } konsentrasi & Ulangan & Ulangan & Ulangan & Ulangan & Ulangan & \multirow{2}{*}{ Rata-rata } \\
\cline { 2 - 6 }$(\%)$ & Ke-1 & Ke-2 & Ke-3 & Ke-4 & Ke-5 & \\
\hline $10 \%$ & 3.456 & 3.360 & 2.567 & 2.890 & 3.125 & 3.079 \\
$15 \%$ & 0 & 0 & 0 & 0 & 0 & 0 \\
$20 \%$ & 0 & 0 & 0 & 0 & 0 & 0 \\
$25 \%$ & 0 & 0 & 0 & 0 & 0 & 0 \\
$30 \%$ & 0 & 0 & 0 & 0 & 0 & 0 \\
Kontrol & 4.944 & 5.936 & 6.160 & 4.232 & 5.904 & 5.435 \\
\hline
\end{tabular}

Konsentrasi $\mathrm{NaCl}$ yang efektif dalam menghambat pertumbuhan Staphylococcus aureus adalah $15 \%$. Konsentrasi ini adalah konsentrasi terkecil dimana koloni Staphylococcus aureus sudah tidak dapat tumbuh. Untuk mengetahui adanya pengaruh dari perlakuan $\mathrm{NaCl}$ terhadap pertumbuhan Staphylococcus aureus maka dilakukan uji statistik. Hasil uji normalitas data dengan menggunakan uji Sgapiro-Wilk, diketahui nilai asymp. Sig $=0,751$. Apabila nilai asymp. Sig $>0,05$ maka dapat dinyatakan bahwa data berdistribusi normal, kemudian dilanjutkan dengan Anova. Berdasarkan hasil uji Anova diperoleh nilai signifikasi 0,000 apabila nilai signifikasi $<0,05$ menunjukkan adanya perbedaan pertumbuhan koloni dari perlakuan berbagai konsentrasi sehingga dapat dilanjutkan ke uji Regresi untuk mengetahui ada tidaknya pengaruh.
Berdasarkan hasil uji analisa statistik menggunakan uji regresi didapatkan nilai signifikasi $=0,000$. Sesuai ketentuan apabila nilai signifikasi $<0.05$ maka dapat dinyatakan bahwa berbagai media nutrien agar yang ditambah $\mathrm{NaCl}$ dengan konsentrasi yang berbeda berpengaruh terhadap pertumbuhan Staphylococcus aureus. Dengan persamaan ( $x=$ konsentrasi, $y=j u m l a h$ koloni). Untuk melihat seberapa besar pengaruh konsentrasi $\mathrm{NaCl}$ terhadap pertumbuhan Staphylococcus aureus, pada jumlah koloni dilakukan analisis koefisien determinasi atau disimbolkan dengan $\mathrm{R}^{2}$ yang merupakan hasil dari pengujian terhadap penurunan jumlah koloni.

\section{Y-Values}

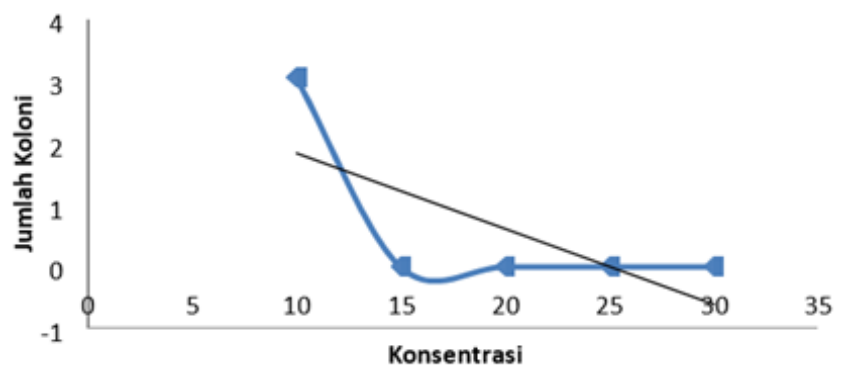

Gambar 1. Grafik penurunan jumlah koloni pada persamaan garis lurus varian konsentrasi $\mathrm{NaCl}$

Nilai $\mathrm{R}$ square yang diperoleh adalah sebesar 0,493 atau 49,3\% nilai ini menyimpulkan bahwa pengaruh konsentrasi $\mathrm{NaCl}$ terhadap pertumbuhan Staphylococcus aureus sebesar $49,3 \%$.

Natrium klorida dapat menghambat pertumbuhan Staphylococcus aureus karena dapat meningkatkan tekanan osmotik substrat yang menyebabkan terjadinya penarikan air dari dalam sel mikroorganisme sehingga sel akan kehilangan air dan mengalami pengerutan hal ini menyebabkan aktifitas mikroorganisme terhambat. Selain itu konsentrasi $\mathrm{NaCl}$ dapat menyebabkan protein mikroba terdenaturasi (Winiati P R, 1992). Natrium klorida juga memiliki daya toksisitas yang tinggi pada mikroba, ionisasi garam akan menghasilkan ion klor yang beracun terhadap mikroorganisme serta dapat memblokir sistem respirasinya (Indarti, 2009).

Hasil penelitian Indarti (2009) pada konsentrasi garam 4\%,6\%, 8\%, 10\%, 12\% belum dapat menghambat pertumbuhan Staphylococcus aureus dan hasilnya pun tidak dapat dihitung. Sedangkan pada konsentrasi $16 \%$, $20 \%, 30 \%, 40 \%$ pertumbuhan koloninya masih tampak hanya saja kerapatanya berkurang, sehingga koloninya dapat dihitung. 
Pertumbuhan ini dapat terlihat pada waktu kontak 20, 30, 40, 50, 60 menit, dimana semakin tinggi waktu kontak yang digunakan maka semakin berkurang pertumbuhan koloni tersebut. Berdasarkan hasil penelitian Indarti menunjukkan bahwa garam dapur pada konsentrasi $4 \%$ tidak mampu menghambat pertumbuhan Staphylococcus aureus dalam waktu 60 menit, sedangkan pada konsentrasi garam dapur $40 \%$ sudah sedikit menghambat pertumbuhan Staphylococcus aureus dalam waktu 60 menit.

Hasil penelitian Dini Ruliani (2010) pengaruh larutan garam dapur terhadap pertumbuhan Staphylococcus aureus pada media nutrient agar menunjukkan terdapat pengaruh larutan garam dapur $(\mathrm{NaCl})$ pada konsentrasi $18 \%$. Sedangkan pada penelitian ini konsentrasi $\mathrm{NaCl} 15 \%$ sudah tidak ada bakteri yang tumbuh. Perbedaan dari hasil penelitian ini disebabkan dari berbagai faktor yang dapat mempengaruhi perkembangbiakan bakteri. Faktor yang menyokong perkembangbiakan bakteri diantaranya adalah temperatur, waktu, kelembaban, oksigen, $\mathrm{pH}$ dan cahaya (Arisman,2012).

Adapun keadaan lingkungan serta temperatur yang digunakan pada penelitian ini adalah untuk temperatur pada inkubator yaitu dengan suhu $37^{\circ} \mathrm{C}$, waktu yang digunakan yaitu selama 24 jam dan $\mathrm{pH}$ yang digunakan adalah $\mathrm{pH}$ netral 7,0 .

Selain faktor-faktor tersebut yang menyebabkan hasil berbeda adalah metode yang digunakan pada saat penelitian. Metode penelitian yang digunakan Indarti (2009) adalah media yang digunakan yaitu media cair Nutrient Broth dengan konsentrasi garam 4\%, $6 \%, 8 \%, 10 \%, 12 \%, 16 \%, 20 \%, 30 \%, 40 \%$ dan masing-masing menggunakan waktu kontak 20,30, 40, 50, 60 menit yang kemudian dilakukan kultur pada media BAP. Sedangkan pada penelitian ini menggunakan media padat Nutrient Agar plat dengan konsentrasi garam $10 \%, 15 \%, 20 \%, 25 \%$ dan $30 \%$ dan tanpa menggunakan waktu kontak.

\section{KESIMPULAN}

Terdapat pengaruh penambahan $\mathrm{NaCl}$ pada media terhadap pertumbuhan Staphylococcus aureus dengan nilai signifikasi 0,000 $(<0,05)$. Konsentrasi $\mathrm{NaCl}$ yang efektif menghambat pertumbuhan Staphylococcus aureus adalah $15 \%$.

\section{SARAN}

Melakukan penelitian tentang pengaruh konsentrasi $\mathrm{NaCl}$ terhadap pertumbuhan
Staphylococcus aureus dari konsentrasi $10 \%$ sampai dengan konsentrasi $15 \%$.

\section{DAFTAR PUSTAKA}

Arisman. (2012). Keracunan Makanan, Buku Ajar IImu Gizi. Jakarta: EGC.

Balaban, N., \& Rasooly, A. (2000). Review Staphylococcal enterotoxins. J.Food Microbiol, 61, 1-10.

Desrosier, N. (2008). Teknologi Pengawetan Pangan, Edisi 3. Jakarta: Penerbit Universitas Indonesia.

Helmiyati AF. (2010). Pengaruh Konsentrasi Tawas terhadap Pertumbuhan Bakteri Gram Positif dan Negatif. Universitas Muhammadiyah Semarang.

Honeyman, A. L., Friedman, H., \& Bendinelli, M. (2001). Staphylococcus aureus infection and disease. Plenum Publishers, 40 (8), 667-671..

Indarti. (2009). Pertumbuhan Staphylococcus aureus pada Media yang Ditambah Garam Dapur. Universitas Muhammadiyah Semarang.

Aristyan, I., Ratna, I., \& Laras, R. (2014). Pengaruh Perbedaan Kadar Garam Terhadap Mutu Organoleptik Dan Mikrobiologis Terasi Rebon (Acetes Sp.). Universitas Diponegoro.

Jaya, D. (2013). Keracunan Massal Di Batulicin Terungkap. Buana Kalimantan News. Kalimantan Selatan..

Jawetz, Melnick, \& Adelberg's. (2008). Mikrobiologi Kedokteran (23rd ed.). Jakarta: Penerbit Buku Kedokteran EGC.

Dini, R. (2010). Pengaruh Larutan Garam Dapur Terhadap Pertumbuhan Staphylococcus aureus Pada Agar Nutrien. Sekolah Tinggi Analis Bakti Asih Bandung.

Srikandi, F. (1993). Analisis Mikrobiologi Pangan. Jakarta: Raja Grafindo Persada. 